\title{
中心静脈カテーテル関連血流感染における適正なドレッシング交換手順の重要性
}

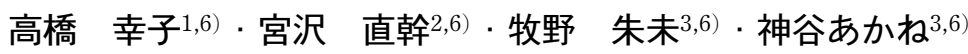 \\ 金子 美玲 4,6$) \cdot$ 親松 隆浩 4,6$) \cdot$ 深沢 貴志 ${ }^{4,6)} \cdot$ 甲斐 純夫5,6)
}

\section{Correct Replacement of Catheter Site Dressing Can Prevent Central Line-Associated Bloodstream Infection}

\author{
Sachiko Takahashi ${ }^{1,6)}$, Naoki MiYaZawa ${ }^{2,6)}$, Akemi Makino ${ }^{3,6)}$, Akane KamiYa ${ }^{3,6}$, \\ Mirei KaneKo ${ }^{4,6)}$, Takahiro Oyamatsu ${ }^{4,6)}$, Takashi Fukasawa ${ }^{4,6)}$ and Sumio KAI ${ }^{5,6}$ \\ ${ }^{1)}$ Department of Nursing, ${ }^{2)}$ Department of Respiratory Medicine, ${ }^{3)}$ Department of Clinical Laboratory, \\ ${ }^{4)}$ Department of Pharmacy, ${ }^{5)}$ Department of Pediatrics, ${ }^{6}$ Infection Control Team, Saiseikai Yokohamashi Nanbu Hospital \\ (2014 年 6 月 6 日 受付 · 2014 年 11 月 25 日 受理)

\begin{abstract}
要旨
中心静脈カテーテル関連感染 (central line-associated bloodstream infection: CLABSI) 対策とし て挿入時のマキシマルバリアプリコーションや挿入時の消毒薬が注目されているが，挿入後のケア に関する検討は少ない. CLABSI 低減の試みとして感染防止対策リンクナース会に扔いて適正な ドレッシング交換の手順書を作成し，全看護師でケアの統一を図った．その介入効果を検討するた めに, 介入前後の CLABSI 率を比較した。その結果, 介入前の 2012 年 4 月から 2013 年 3 月まで の CLABSI 率は 4.34 件/1,000 カテーテル日 (医療器具使用比 0.054 ) であったのに対し, 介入後の 2013 年 4 月から 2014 年 3 月までの CLABSI 率は 1.52 件/1,000 カテーテル日 (医療器具使用比 0.051)であった．日常のドレッシング交換時に正しい操作を行うという教育によりカテーテル感染 率を低下させることができ，非常に有用な対策であると考えられた。
\end{abstract}

Key words : 中心静脈カテーテル法, カテーテル感染, 創傷被覆材

\section{はじめに}

中心静脈カテーテル関連血流感染 (central line-associated bloodstream infection: CLABSI)は時に重篤な 病態を引き起こし, 入院期間の延長や医療費の増大の原 因となり，その対策は非常に重要である1). CLABSI 対 策として挿入時のマキシマルバリアプリコーションや挿 入時の消毒薬が注目されているが，挿入後のケアに関す る検討は少ない，当院ではカテーテル挿入時にマキシマ ルバリアプリコーションを行っているにもかかわらず, National Healthcare Safety Network (NHSN), Japanese Healthcare-Associated Infections Surveillance (JHAIS) のベンチマーク2) と比較して感染率が高かったため, 挿 入後のケアに注目した。 今回，我々はCLABSI 対策と

恩賜財団済生会横浜市南部病院 ${ }^{1)}$ 看護部, ${ }^{2}$ 呼吸器内科, ${ }^{3)}$ 中 央検查部，4)薬剂部，5) 小児科，6)感染制御チーム
して，中心静脈カテーテルのドレッシング交換時の適切 な手順書を作成, 全看護師で共有し遵守することで感染 率が減少するのではないかと考え，その成果を検討した。

万法

済生会横浜市南部病院 (26 診療科, 500 床)のリンク ナース会は感染管理認定看護師を委員長として，担当看 護師長 1 人, 各部署より 1 名ずつ 5 年以上の経験を有 する看護師を選出し, 計 15 名で構成されている(図 1). 各部署のリンクナースは感染防止対策のリーダー的 役割を担っており，スタッフの教育を行っている.リン クナース会の課題として中心静脈カテーテル挿入患者を ケアする一般病棟 (すべて各診療科混合病棟) と集中ケア ユニット (ICU)のリンクナースを中心に， 2013 年 4 月 にCLABSI 率低下のための介入を行った. 


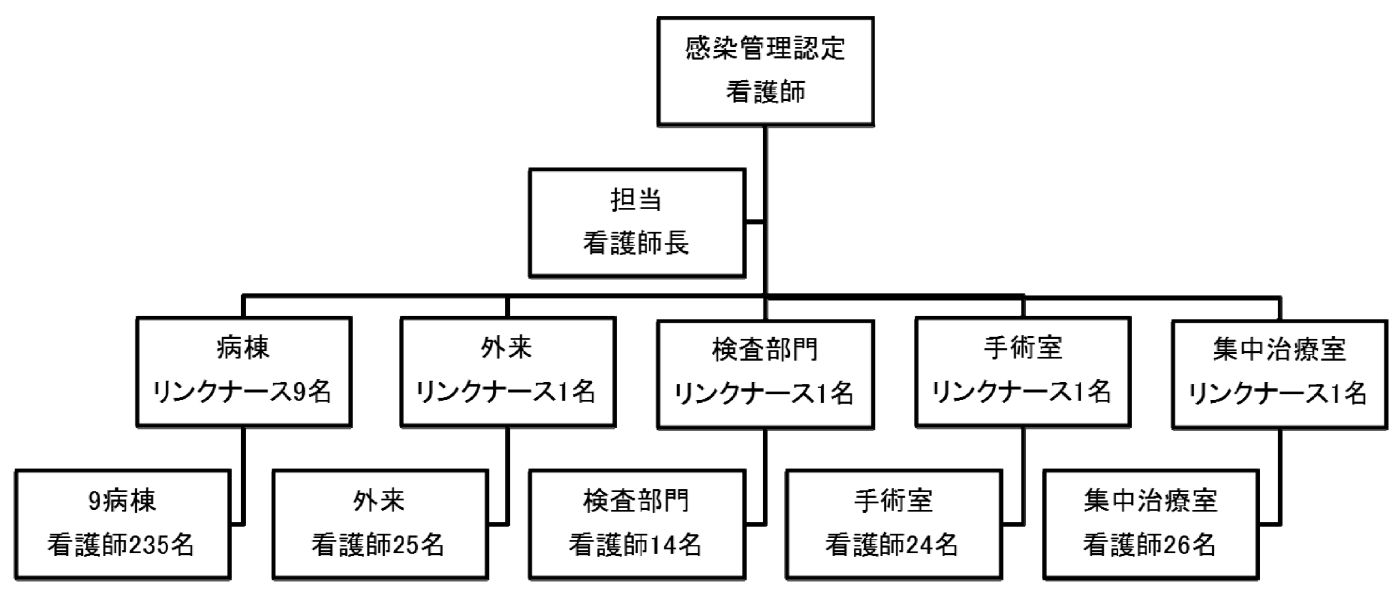

図1感染対策リンクナース会組織

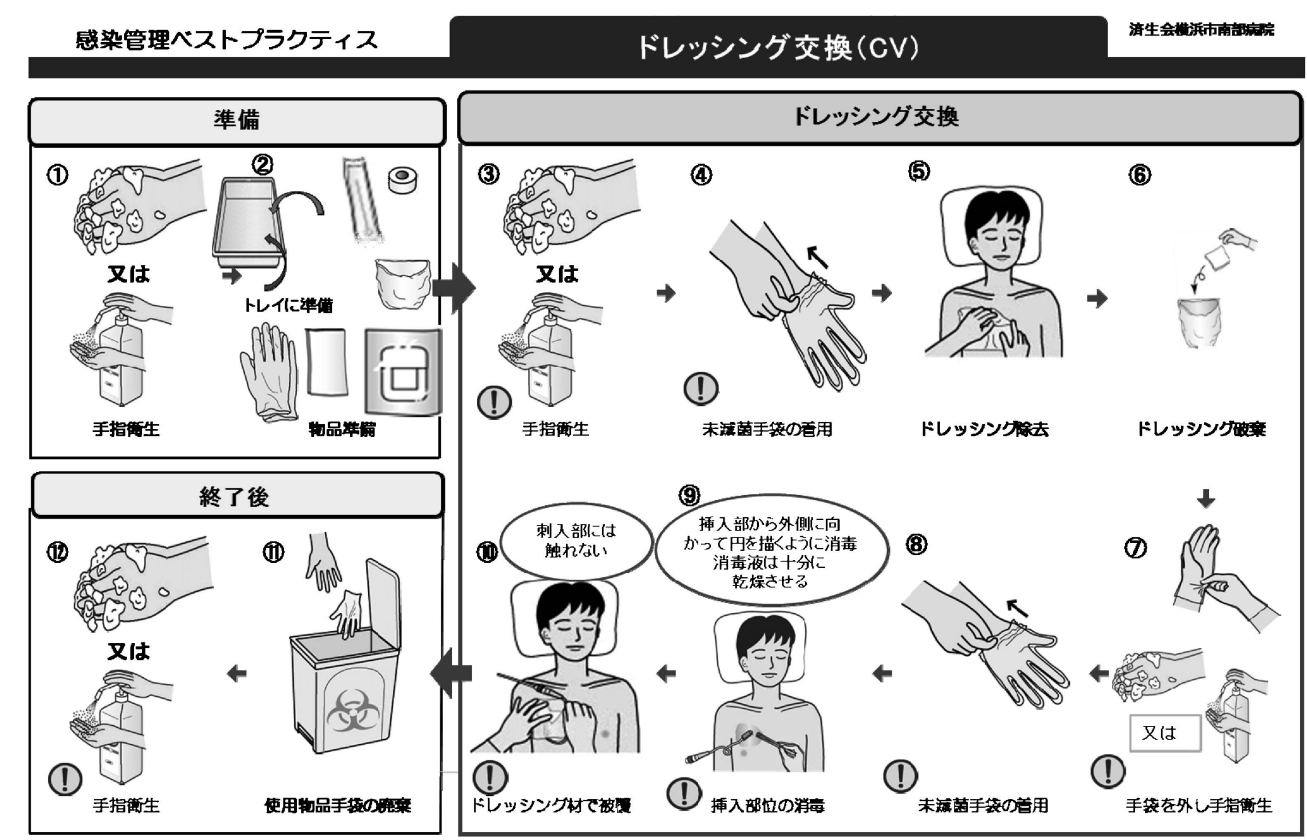

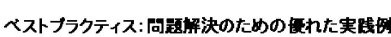

(1) 赤文字:EBMに基つき強く惟無されているところ

図 2 中心静脈カテーテル刺入部ドレッシング交換イラスト手順書 「感染管理ベストプラクティス第 2 版事例集」を参考に作成した ${ }^{3)}$.

1. 感染率低下のための介入

1）リンクナース会において, 中心静脈カテーテル刺 入部の適正なドレッシング交換イラスト手順書(図 2)を 作成し, 中心静脈カテーテル刺入部ケアを行っている一 般病棟 10 部署, ICU 1 部署に配布した. 手順書は「感 染管理ベストプラクティス第 2 版事例集」を参考に作 成した ${ }^{3)}$. 各部署のリンクナースにスタッフ教育を依 頼, 手順書に従い刺入部ケアに関わる看護スタッフ全員 の正しいケアの統一を行った．2) 刺入部消毒薬を 10\% ポビドンヨード (PVI) から 1\%クロルヘキシジンアル コール製剂(CHG-AL) (ヘキザック AL 1\%綿棒 $12^{\circledR}$, 吉 田製薬秼) に変更した。
2. CLABSI サーベイランス

2012 年 4 月から 2014 年 3 月までの当院入院中の中 心静脈カテーテル挿入全症例を対象に電子カルテ (NEC MegaOakHR バージョン R3.0.5) 文書照会から中心静脈 カテーテル挿入留置術説明書・同意書を検索し，それを 基に電子カルテより患者基本情報や CLABSI 判定に必 要な情報を得た。

中心静脈カテーテル (非皮下トンネル中心静脈カテー テル, 透析カテーテル, 肺動脈カテーテル, 末梢拥入中 心静脈カテーテル)を留置された全入院患者に扔いて, NHSN の定義 ${ }^{4}$ を用い，1）1 回以上の血液培養で病原体 が検出され，かつ検出された病原体はカテーテル以外の 
感染巣と関連がない，または，2） $38^{\circ} \mathrm{C}$ を超える発熱， 悪寒，低血圧のいずれかが認められ，一般の皮膚污染菌 が異なる機会に採取された 2 回以上の血液培養から検 出された場合をCLABSI と判定した. 判定は医師 2 名, 看護師 1 名, 薬剤師 3 名, 臨床検査技師 2 名で構 成された院内感染制御チームで行った.

感染率は CLABSI と判定された件数/延べ医療器具使 用日数 $\times 1,000$, 医療器具使用比は延べ医療器具使用日 数/延べ入院患者数とし, 各月ごとに計算し介入前後で 比較した.

\section{3. 統計}

介入前後 1 年間の各月 CLABSI 率および医療器具使 用比は Mann-Whitney U test を用いて検討し, 有意水 準を 5\%とした。

\section{結 果}

当院では 2011 年 7 月より全入院患者を対象とした CLABSI サーベイランスを行って抢り，その感染率と 医療器具使用比の推移を示す (表 1, 図 3). 2013 年 4 月 に感染率の低下を目標にリンクナース会が介入し, 一般 病棟，ICUに所属する全看護職員に教育したことによ り，以後の CLABSI 率の低下が認められた.

介入前の感染率は, 2012 年 4 月〜 2013 年 3 月は
4.34 (医療器具使用比 0.054 ) であったのに対し, 介入後 の 2013 年 4 月 2014 年 3 月は 1.52 (医療器具使用比 0.051) と著明に減少した (図 4). 図 5 に示す通り，月別 の医療器具使用比は介入前後で有意差なし $(\mathrm{p}=0.542)$ で あったが，感染率は有意に減少した $(p=0.003)$.

中心静脈カテーテルの平均留置日数は 2012 年 4 月～ 2013 年 3 月が 13.0 日/本, 2013 年 4 月 2014 年 3 月 は 14.5 日/本であった.

挿入部位別カテーテル感染件数を表 2 に示す. 2012 年 4 月 2013 年 3 月に比し 2013 年 4 月 2014 年 3 月 では，いずれの挿入部位でも感染件数は著減している が，感染したカテーテル挿入部位の割合は大きな変化が 認められなかった.

表 2 挿入部位別中心静脈カテーテル感染件数

\begin{tabular}{lcc}
\hline & $\begin{array}{c}2012 \text { 年 4月〜 } \\
2013 \text { 年 3月 }\end{array}$ & $\begin{array}{c}2013 \text { 年 4月〜 } \\
2014 \text { 年 3月 }\end{array}$ \\
\hline 鼠径静脈 & $12 / 33(36.4 \%)$ & $5 / 11(45.5 \%)$ \\
内頸静脈 & $14 / 33(42.4 \%)$ & $4 / 11(36.4 \%)$ \\
鎖骨下静脈 & $7 / 33(21.2 \%)$ & $2 / 11(18.2 \%)$ \\
肘部皮静脈 & $0 / 33(0.0 \%)$ & $0 / 11(0.0 \%)$ \\
\hline
\end{tabular}

表 1 月別感染件数

\begin{tabular}{|c|c|c|c|c|c|}
\hline & 述べ入院患者数 & 述べ医療器具使用日数 & 感染件数 & 感染率 & 医療器具使用比 \\
\hline 2012 年 4 月 & 11749 & 681 & 3 & 4.40 & 0.058 \\
\hline 5 月 & 12261 & 671 & 3 & 4.47 & 0.055 \\
\hline 6 月 & 11949 & 597 & 3 & 5.02 & 0.050 \\
\hline 7 月 & 12594 & 722 & 2 & 2.77 & 0.057 \\
\hline 8 月 & 12891 & 608 & 3 & 4.93 & 0.047 \\
\hline 9 月 & 12302 & 667 & 4 & 6.23 & 0.052 \\
\hline 10 月 & 12425 & 642 & 4 & 6.23 & 0.052 \\
\hline 11 月 & 11977 & 724 & 4 & 5.52 & 0.060 \\
\hline 12 月 & 12267 & 666 & 4 & 6.00 & 0.054 \\
\hline 2013 年 1 月 & 11713 & 550 & 3 & 5.54 & 0.047 \\
\hline 2 月 & 11506 & 647 & 1 & 1.54 & 0.056 \\
\hline 3 月 & 12368 & 661 & 0 & 0.00 & 0.53 \\
\hline 4月 & 11197 & 534 & 1 & 1.87 & 0.047 \\
\hline 5 月 & 11416 & 658 & 2 & 3.04 & 0.057 \\
\hline 6 月 & 11385 & 677 & 0 & 0.00 & 0.059 \\
\hline 7 月 & 12042 & 576 & 2 & 2.90 & 0.055 \\
\hline 8 月 & 12410 & 689 & 2 & 2.90 & 0.055 \\
\hline 9 月 & 11433 & 571 & 1 & 1.75 & 0.050 \\
\hline 10 月 & 12308 & 568 & 0 & 0.00 & 0.046 \\
\hline 11 月 & 11730 & 647 & 1 & 1.54 & 0.055 \\
\hline 12 月 & 11637 & 493 & 1 & 2.02 & 0.042 \\
\hline 2014 年 1 月 & 11345 & 526 & 0 & 0.00 & 0.046 \\
\hline 2 月 & 11348 & 592 & 0 & 0.00 & 0.052 \\
\hline 3 月 & 11365 & 680 & 1 & 1.47 & 0.059 \\
\hline
\end{tabular}




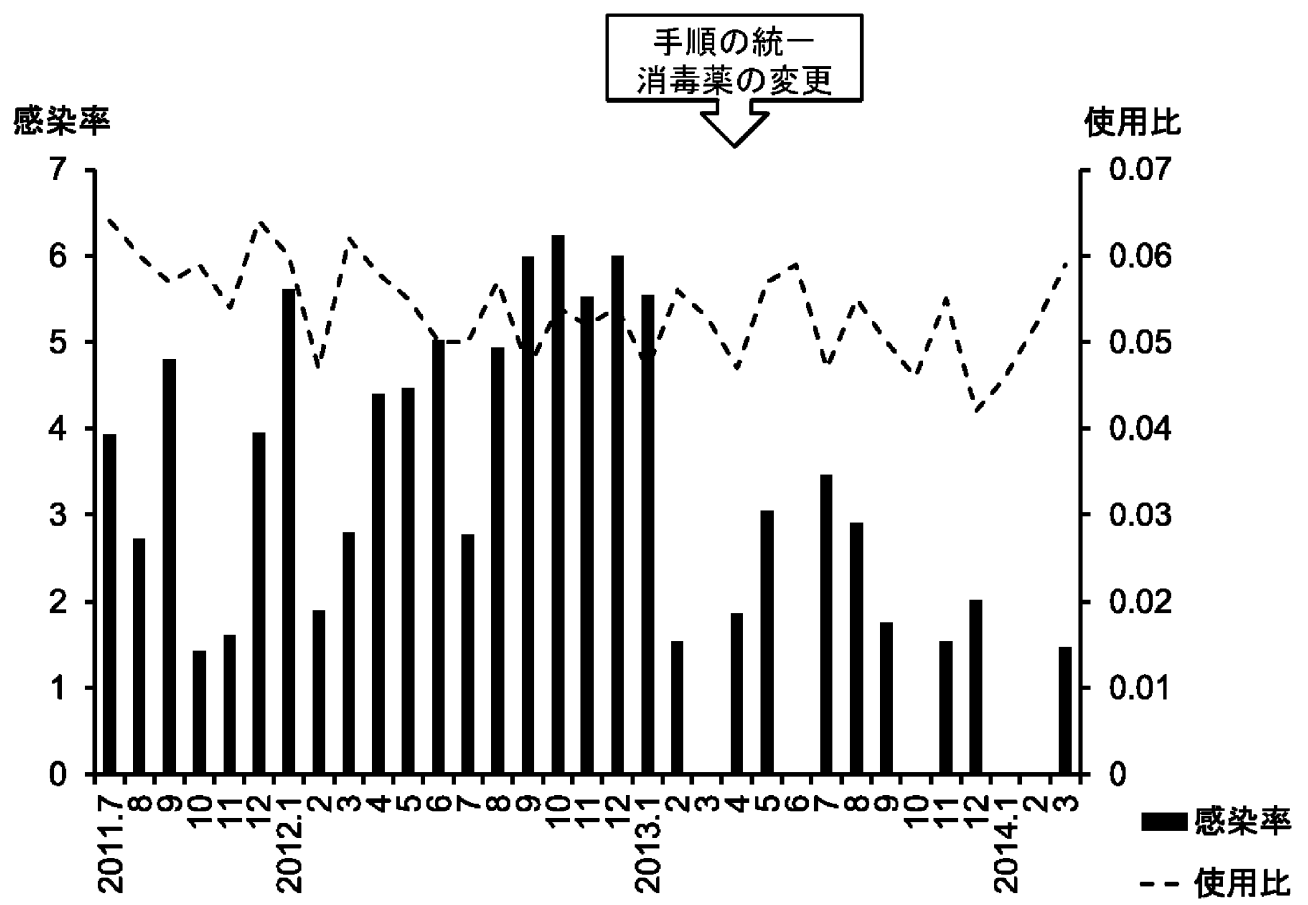

図 3 中心静脈力テーテル感染(CLABSI)率之医療器具使用比の推移(2011年 7 月より2014年 3 月まで)

感染率は感染件数/カテーテル使用日数 $\times 1,000$, 医療器具使用比は延ベカテーテル使用日数/延べ入院患者数で求めた.

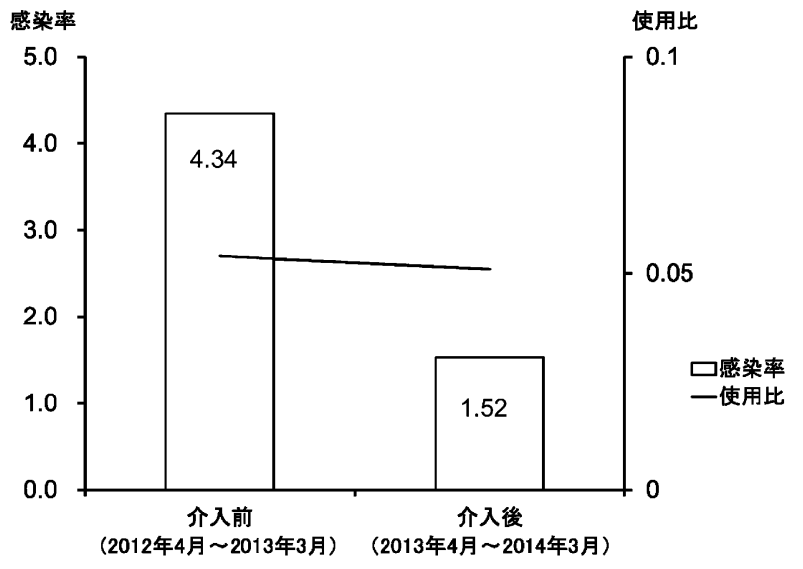

図 4 介入前後の医療器具使用比と中心静脈カテーテル感 染(CLABSI)率

感染率(件/1,000 カテーテル日) は介入前 1 年間 4.34 であったのに対し, 介入後 1 年間は 1.52 に低 下した。

考 察

当院は全入院患者を対象とした CLABSI サーベイラ ンスを行っているが，日本のデバイス関連感染サーベイ ランスであるJHAIS の「臨床的敗血症なし」と比較す ると，当院に打る 2012 年 4 月〜 2013 年 3 月の感染 率は 75\%～90\%の間に位置しており，ICUを対象とし たものではあるが JHAIS の提示するベンチマークデー タ2）と比較して平均より高いという結果であった。サー ベイランスの結果は院内の感染防止に関わる各委員会等
にフィードバックしているが，感染防止対策リンクナー ス会に拈いて，CLABSI 率の低減を 2013 年の活動目標 の一つとした。

当院の CLABSI 率が高い理由としてドレッシング交 換時の手順が統一されていない事が考えられたため，リ ンクナースが主体的に適正なドレッシング交換イラスト 手順書を作成し，実験的に 1 つの病棟で 2012 年 12 月 〜2013 年 1 月にチェックリストを用いたスタッフ教育 を行ったところ，手順の改善が認められた。具体的に は，手順書作成前にはドレッシング材除去前後で手指衛 生を行っていなかった等，手指衛生のタイミングが適正 でなかったことがリンクナースからの聞き取り調査で判 明した。

このことから一部の部署にとどまらず，2013 年 4 月 に中心静脈カテーテル刺入部ケアを行っている全部署 (一般病棟, ICU)にイラスト手順書を配布し，リンク ナースにスタッフ教育を依頼, 刺入部ケアに関わる看護 職員全員の正しいケアの統一を行った.

その結果, CLABSI は介入後に著明に減少した。挿 入時の術者 (医師)の操作や平均留置日数, カテーテル感 染事例の挿入部位の割合は介入前後で変化がみられなか ったことから，この減少効果は看護職員による適正なド レッシング交換手順の統一にあると考えられた。 また， この手順の統一を促すという指導自体が「リンクナース 会の活動目標が CLABSI 率の低減である」との周知々 なり，CLABSI 防止の意識を高め，感染率低減につな 
A.

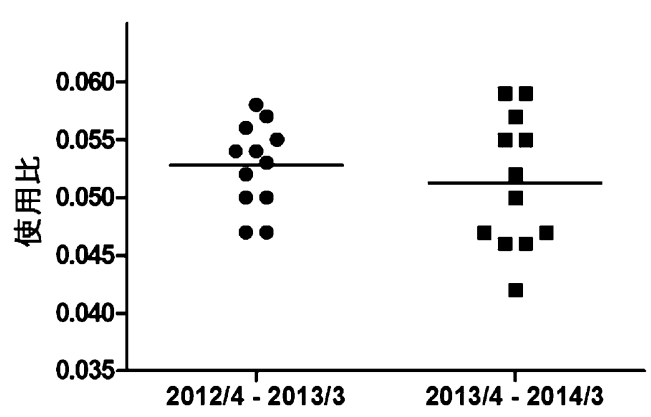

B.

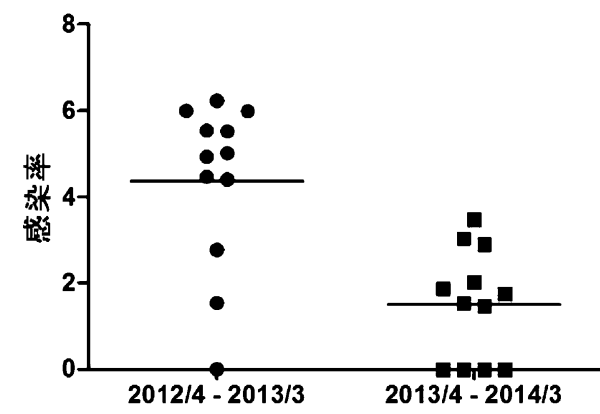

図 5 介入前後 1 年間各月の医療器具使用比と中心静脈力テーテル感染 (CLABSI) 率の比較

A : 医療器具使用比, B : CLABSI 率. 医療器具使用比は介入前後で差はなかった $(p=0.542)$ のに対し，感染率は有意に低下し た $(\mathrm{p}=0.003)$.

がった可能性も考えられた.

Warren らは米国500床の市中病院において, CLABSI 予防に関する 10 ページの自己学習教材, 講 義, ポスター掲示を用いて, ICUに従事する医師, 看 護師に対し教育することによって, ICUにおける CLABSI 率は 4.9 から 2.1 に減少したと報告してい る5). 当院も同規模の市中病院であるが, ICUにとどま らず病院全体の看護職員に，1枚の手順書を遵守するよ うに教育することによって, 院内の CLABSI 率を 4.34 から 1.52 に減ずることに成功した.

CHG-AL 乾燥までの待ち時間は 30〜 40 秒と短いのに 対し, PVI は乾燥するまで(あるいは 2 分以上) 待たな ければ消毒効果を発揮しない。また, 2011 年の Healthcare Infection Control Practices Advisory Committee (HICPAC) ガイドライン1)では，中心静脈カテー テルおよび末梢動脈カテーテル挿入部位の消毒について 0.5\%を超える濃度の CHG-AL が推奨されていたため, 原則として挿入部位の消毒を 10\% PVI から 1\% CHGALに変更した。このことも感染率低減につながった可 能性がある。

しかし後方視的に検討すると, 試験的に一部の病棟 (血液内科を含む病棟)で, 2012 年 11 月より消毒薬を 1\% CHG-AL に変更したところ, 感染率は変更前 5 カ 月間で 6.77 (医療器具使用比 0.125)であったのに対し, 変更後 5 力月間では 6.51 (医療器具使用比 0.076 ) と変化 は認められなかった.すなわち, 当院においては, ドレ ッシング交換時の消毒薬を変更したというだけでは CLABSI 率低減にあまり寄与しないと推察される。同 病棟でドレッシング交換手順を統一したところ, 統一以 前の 2012 年 4 月 2013 年 3 月は感染率 6.71 (医療器具 使用比 0.091 ) であったのに対し, 統一後の 2013 年 4 月 $\sim 2014$ 年 3 月では 1.50 (医療器具使用比 0.128 ) と低下 して拈り,ケアの統一により感染率が減少したことを裏 付ける結果であった.
HICPACガイドラインにおける>0.5\% CHG-ALの 推奨根拠として，CHG-AL は PVI と比較してカテーテ ル感染リスクが $49 \%$ 低いとの報告6,7) や，本邦での $10 \%$ PVI と $1 \%$ CHG-AL の殺菌力を比較した報告8,9)がある が，ドレッシング交換に $1 \%$ CHG-AL を用いる有用性 は, その殺菌力の強さよりむしろ乾燥時間が短いという 利便性にあり，適正なケアが容易となることなのではな いかと考えられる.

中心静脈カテーテル挿入時には，マキシマルバリアプ リコーションが推奨されている11が, 鶴岡らはドレッシ ング交換時の装備に注目した ${ }^{10)}$ 。無菌室で造血幹細胞 移植を受けた症例を対象に，ドレッシング交換時の装備 を未滅菌手袋, 滅菌手袋, およびマキシマルバリアプリ コーションの 3 方法に無作為に割り付けて比較検討し た結果，マキシマルバリアプリコーションを行った場合 に CLABSI 発生率が低い傾向があったものの，3 方法 で有意差は認められなかったと報告されている，このこ とから，現時点ではドレッシング交換時には，高コスト のマキシマルバリアプリコーションを行うまでの必要は なく, 今回の介入のような正しいタイミングの手指衛 生, 未滅菌手袋によるケア, 適切な手順の遵守で十分で あると思われる。

CLABSI の低減にはマキシマルバリアプリコーショ ンなど挿入時の操作ばかりが注目されているが，カテー テルの管理を行う医療従事者を教育及びトレーニング し，日常のドレッシング交換時に正しい操作を行うこと により，CLABSI 率は減少することが明らかになっ た.これらの対策は，低コストで高い効果を生むため非 常に有用であり，多くの医療機関で実践されることが期 待される.

利益相反について : 利益相反はない. 
文献

1) O'Grady NP, Alexander M, Burns LA, Dellinger EP, Garland J, Heard SO, et al.; the Healthcare Infection Control Practices Advisory Committee (HICPAC): 2011 Guidelines for the Prevention of Intravascular Catheter-Related Infections. http://www.cdc.gov/hicpac/BSI/BSI-guidelines-2011.html: accessed May 12, 2014.

2）日本環境感染学会 JHAIS 委員会 : 医療器具サーベイ ランスデータ.中心ライン関連血流感染. http:// www.kankyokansen.org / modules / iinkai / index.php? content_id $=4: 2014$ 年 9 月 20 日現在

3）近畿感染管理ベストプラクティス研究会, 東北感染制 御ネットワークベストプラクティス部会(編)：感染管 理ベストプラクティス第 2 版事例集, ドレッシング交 換 $(\mathrm{CV})$. 花王プロフェッショナル・サービス, 大阪, 2009, p 34.

4) Horan TC, Andrus M, Dudeck MA: CDC/NHSN surveillance definition of health care-associated infection and criteria for specific types of infections in the acute care setting. Am J Infect Control 2008; 36: 309-32.

5) Warren DK, Zack JE, Cox MJ, Cohen MM, Fraser VJ: An educational intervention to prevent catheter-as- sociated bloodstream infections in a non-teaching community medical center. Crit Care Med 2003; 31: 195963.

6) 萬 知子 : 中心静脈カテーテル関連合併症一機械的合 併症と血流感染一。日臨麻会誌 2014; 34(1): 11-6.

7) Chaiyakunapruk N, Veenstra DL, Lipsky BA, Saint S: Chlorhexidine compared with povidone-iodine solution for vascular catheter-site care: a meta-analysis. Ann Intern Med 2002; 136: 792-801.

8）谷村久美, 大久保憲：血管内留置カテーテル挿入部位 の皮膚消毒に関する検討。環境感染誌 2010; 25 (5): 281-5.

9）西原 豊, 梶浦 工, 横田勝弘, 小林寬伊, 菅原えり さ，大久保憲：カテーテル関連血流感染予防に向けた 皮膚消毒薬としての $1 \mathrm{w} / \mathrm{v} \%$ クルヘキシジン $(\mathrm{CHG})$ エタノールの有効性と安全性. 環境感染誌 2013; 28(3): 131-7.

10）鶴岡恵子，常岡英弘 : 中心静脈カテーテル挿入部の感 染予防におけるマキシマルバリアプリコーションの評 価. 環境感染誌 2013; 28(6): 348-54.

〔連絡先 : 干234-8503 横浜市港南区港南台 3-2-10 恩賜財団済生会横浜市南部病院感染管理室 高橋幸子 E-mail: takahashisa@nanbu.saiseikai.or.jp]

\title{
Correct Replacement of Catheter Site Dressing Can Prevent Central Line-Associated Bloodstream Infection
}

\author{
Sachiko TAKAHASHI ${ }^{1,6)}$, Naoki MiYaZAWA ${ }^{2,6)}$, Akemi MAKINO ${ }^{3,6)}$, Akane KAMIYA ${ }^{3,6)}$, \\ Mirei KaneKo ${ }^{4,6)}$, Takahiro OYamatsu ${ }^{4,6)}$, Takashi Fukasawa ${ }^{4,6)}$ and Sumio KaI ${ }^{5,6)}$ \\ ${ }^{1)}$ Department of Nursing, ${ }^{2)}$ Department of Respiratory Medicine, ${ }^{3)}$ Department of Clinical Laboratory, \\ ${ }^{4)}$ Department of Pharmacy, 5) Department of Pediatrics, ${ }^{6}$ Infection Control Team, Saiseikai Yokohamashi Nanbu Hospital
}

\begin{abstract}
Maximum sterile barrier insertion and use of antiseptics during insertion are important for preventing central line-associated bloodstream infection (CLABSI). However, few studies have investigated the effect of medical care after the insertion of catheters. A procedure manual was developed showing the correct way to replace the intravascular catheter site dressing, and directed every nurse in charge to follow the manual. After standardizing the procedure, the CLABSI rate was compared before and after intervention. The CLABSI rate was 4.34 cases/1,000 catheter-days in the pre-intervention period (April 2012-March 2013) vs. 1.52 in the post-intervention period (April 2013-March 2014). This educational intervention focused on correct replacement of the catheter site dressing resulted in a significant decrease in the incidence of CLABSI.
\end{abstract}

Key words : central venous catheter, bloodstream infection, dressing on intravascular catheter 